\title{
Fortune, Felicity and Happiness in the Early Modern Period
}

\author{
Introduction
}

Katrin Röder and Christoph Singer

\begin{abstract}
OH happiness! our being's end and aim!
Good, pleasure, ease, content! whate'er thy name:

That something still which prompts th' eternal sigh,

For which we bear to live, or dare to die ...

Fix'd to no spot is happiness sincere,

'Tis no where to be found, or ev'ry where:

'Tis never to be bought, but always free,

And fled from monarchs, St. John! dwells with thee. ...

Some place the bliss in action, some in ease,

Those call it pleasure, and contentment these ...

Who thus define it, say they more or less

Than this, that happiness is happiness? ... ${ }^{1}$
\end{abstract}

Alexander Pope's lines from the Essay on Man (1734) suggest the richness, diversity and overwhelming, transgressive nature of the concept of happiness. In the above quotation, happiness seems to be curiously self-evident and inconclusive at the same time. It is the central motivation for any action or nonaction, all-pervasive, omnipresent and elusive. The obviousness with which Pope uses the word 'happiness' for so many different states of existence (material wealth, flourishing, bliss, the good life, the common good) is, however, the result of a long process of semantic change that is convincingly described by Phil Withington: ${ }^{2}$ being 'derived from the Old Norse noun hap, meaning luck or fortune', the word 'happiness' was, according to Withington's findings, first used by William Caxton in his translation of Raoul Lefèvre's French History of Troy. ${ }^{3}$ The addition of the English suffix 'ness' to the adjective 'happy' denotes 'the quality and state of hap (i.e. fortune) or the circumstances and phenomena that exemplified such a condition.' ${ }^{4}$ The word changed its meaning from denoting good luck and favourable external (providential) conditions to signifying 'the active pursuit of virtue and the common good'. ${ }^{5}$ Happiness became an umbrella term referring to a 'commonplace mixture of physical well-being and psychological content', to the individual and collective desire for and pursuit of 
'public improvement', autonomy, liberty, 'consumer self-interest and national aggrandisement'. ${ }^{6}$

The early modern period was defined by a great variety of conceptions that denote aspects of the umbrella term 'happiness' described by Withington. They were, however, linked to different words (e.g. 'fortune', 'felicity', 'blessedness', 'pleasure', 'contentment'), they existed simultaneously (often in one and the same text) and interacted on multiple textual levels. The early modern concept denoting the workings of fortune was a pervasive one, famously represented in the Mirror for Magistrates (1559-1610), a continuation of John Lydgate's Fall of Princes (itself based on Giovanni Boccaccio's De Casibus Virorum Illustrium). Although the inexorable turns of luck stood in a close connection with human virtues (as the Machiavellian notions of virtù and desire suggest), ${ }^{7}$ the early modern concept of fortune emphasised the 'hap' of happiness. ${ }^{8}$ It conceived of states of material flourishing and health as being contingent upon circumstances in the world. Hence, they were understood as being unstable and beyond the control of individual subjects. Isabella Whitney's poem 'A Careful Complaint by the Unfortunate Author' from A Sweet Nosegay (1573) uses the word 'hap' in this sense. ' The speaker, comparing herself to Virgil's Dido, Queen of Carthage, sees the reasons for her unhappiness in the absence of the state of worldly flourishing and health. She points out that women's happiness depends on the 'retchlesse wyll' of men in a patriarchal society ${ }^{10}$ and problematises the severe consequences of male betrayal in this context. Lady Mary Wroth's Urania (1621), a text that uses 'hap' in a similar sense, affirms female characters' desires and mourns their unhappiness that originates in a lack of subjecthood and material prosperity. ${ }^{11}$

Whereas Adam Potkay, Paul Slack, Sara Ahmed, Paul Dolan and William Davies assume that the modern notion of happiness originated in the seventeenth century (especially in Locke's Essay Concerning Human Understanding and the rise of utilitarianism), Phil Withington dates the origin of the modern notion of happiness in the sixteenth century and shows its complex history of semantic change in the early modern period. ${ }^{12}$ Furthermore, while Keith Thomas investigated the role of values in early modern literature and their significance for states of happiness (focusing on happiness as a desire for or pursuit of assets and goals like military prowess, rewards of labour, social acknowledgement, a high social position, prosperity, honour, friendship, marriage, children, fame and immortality), ${ }^{13}$ the chapters in Suffering and Happiness in England 1550-1850 explore happiness as a word with a remarkable semantic shift and an enormous scope of meaning. They argue convincingly that the history of emotions 'cannot be other than a history of ideas and representations. ${ }^{14}$ However, the methodological approach of the volume, despite its appreciation of the 'conceptual mutability' of happiness ${ }^{15}$ is largely teleological. It highlights that 'happiness' gradually acquires the later (utilitarian) meaning of physical well-being, psychological content and public improvement ${ }^{16}$ but it lacks the conceptual frame for an analysis of the complex semantic negotiations of different conceptions of happiness in specific texts. ${ }^{17}$ 
This themed issue shows that semantic transitions and the creation of 'conceptual mutability' are only a part of the 'semantic work' that early modern texts perform when they discuss different notions of happiness..$^{18}$ It draws on and intends to complicate the important findings gathered in Suffering and Happiness in England 1550-1850, exploring the notions of fortune, felicity and happiness (including closely related ones like contentment and pleasure as well as the role of desire) not only as words but also as discourses. Michel Foucault's work on the genealogy of ethics offers a productive framework for the exploration of the many ways in which early modern texts negotiate, appropriate and interrogate different concepts of happiness. ${ }^{19}$ The works investigated in the articles of this issue (even those less directly linked to the modes of notebook or self writing) create fissures, frictions and tensions between and within different conceptions of happiness in the early modern period. They explore the ways in which what is perceived to be one individual's or one nation's happiness and pleasure can mean or be based upon the unhappiness and suffering of another/others. Furthermore, many texts show how happiness is turned into its opposite or undermined, that happiness is unattainable and that unhappiness and suffering underlie all states of happiness and all forms of attachment (at least in this world). As a consequence, the articles discuss concepts of happiness as unstable, contested, sometimes indeterminate categories. They examine the contingency and interdependence of states of unhappiness and happiness instead of reducing their relationship to a linear sequence or an alternation of periods of suffering, lack, pain or unease and times of pleasure (defined as the absence of pain) and affluence..$^{20}$ In some early modern texts, unhappiness and suffering are depicted as conceptual opposites of happiness, they function as a 'spur to improvement' (as in Protestantism and in a large part of utilitarian thought) ${ }^{21}$ or as a stimulus for the imagination of the possibility of happiness..$^{22}$ However, the articles in this issue demonstrate that in the early modern period, the notion of unhappiness is often an ineradicable constitutive part of the concept of happiness. They show that the striving for happiness and the endorsement and normativity of specific notions of happiness can be based upon as well as be the cause of unhappiness. Foucault's genealogy of ethics is productive for this kind of analysis because it enables the investigation of a variety of relationships between different concepts of (un)happiness. It is a useful framework for literary and cultural discourse analysis because it shows that the concepts of happiness are informed by and contingent upon norms and notions of power and (self-)government. ${ }^{23}$ On the other hand, Foucault's genealogy of ethics illustrates that the discourses of (un)happiness cannot be limited to their repressive function. They represent an aesthetic mode and have formative effects, constituting and shaping forms of life, bodies, selves, philosophies of government, but also verbal texts and works of visual and musical art. ${ }^{24}$

Stephen Greenblatt's exploration of early modern processes of self-fashioning and especially his analyses of More's Utopia illustrate the significance and topicality of this approach. Whereas Renaissance Self-Fashioning focuses on processes of identity formation through submission to authority and self- 
cancellation and on the anamorphic techniques through which the text as a form of "hypothetical writing" constantly questions its own status together with the world and the selves constructed in it, ${ }^{25}$ Greenblatt's reading of Utopia from 2010 concentrates on the impact of materialism and the formative dimension of hedonism. In his approach from 1980, Greenblatt comments on the role of pleasure but above all on its regulation through panoptical surveillance and normative notions of honour and shame. ${ }^{26}$ In Greenblatt's 2010 reading, by contrast, Utopia's response to Lucretius's De rerum natura becomes the central influence that shapes More's entire text. ${ }^{27}$ More's book, however, also shows the dark side of Utopian hedonism, for example its relation to colonialism. As Karl Hardy states, it is precisely the Utopians' philosophy of a 'maximization of human pleasure and welfare' that is contingent upon the 'instrumentalization of ... the "other-than-human" in the service of humanity alongside the dehumanization of Indigenous peoples'.28 Raphael Hythlodaeus does not criticise the Utopians' execution of colonialist 'property rights', that is, their seizure of the "natives" land, their expulsion of the 'natives' and their use of violence against them. The strategies of self-contradiction, irony and paradox that define the text, however, expose the expulsion of the 'natives' as a very problematic, disturbing part of the hedonistic philosophy of the colonists who pride themselves on their rejection of the idea of property and their aversion to territorial expansion. ${ }^{29}$

This themed issue explores the ways in which early modern texts of different genres negotiate, appropriate and challenge the heterogeneous conceptions of fortune, felicity and happiness. It views these texts as cultural resources that continue to interrogate and complicate our understanding of concepts and discourses of (un)happiness.

In his analysis of Blaise Pascal's Pensées and his Provincial Letters, Michael Moriarty explores the texts' speculative negotiations and appropriations of hedonistic, Aristotelian and Christian conceptions of happiness. He argues that although Pascal acknowledges the hedonistic motivation of actions and thoughts, he considers universal, unlimited happiness to be unattainable in a material world that offers transient pleasures through which humans distract themselves from the loss of God and the knowledge of their mortality. This tragic consciousness, Moriarty shows, remains the underlying condition of all states of earthly happiness in Pascal's texts.

Through an analysis of visual art by Donatello, Lombardo, Damini and Giotto, Graham Holderness's article examines the central role of the heart for early modern conceptions of happiness. It demonstrates the influence of Aristotelian political philosophy on William Harvey's treatise De Motu Cordis, especially his discussion of the function of the heart and the circulation of the blood (expressed in his metaphor of the heart as a 'household-god'). Furthermore, Holderness explores the impact of Harvey's description of the function of the heart on Thomas Hobbes's notion of the common good in Leviathan.

John Storey's contribution describes Thomas More's Utopia as the founding text of radical utopianism. It argues that Utopia does not depict a perfect com- 
monwealth but rather raises the question of happiness, that is, the question of the possibility of better or different forms of life and of society. Through this strategy, Storey shows, More's text defamiliarizes and interrogates sixteenthcentury historical reality in England.

In his article 'Absent Felicity', Andrew Sanders demonstrates that Shakespeare uses 'happiness' and 'happy' to refer to favourable external circumstances that are not fully in the purview of human control and therefore elusive, precarious, unstable, and always (both indirectly and directly) linked to unhappiness. By contrast, the notion of happiness as a goal that can be pursued by man in this world can be found at the end of John Milton's Paradise Lost. Furthermore, Sanders shows that Shakespeare's and Milton's works challenge pastoral notions of happiness.

Joachim Frenk examines the contrastive strategies that Sir Philip Sidney devises in his appropriation of the discourse and rhetoric of happiness in his Old and his New Arcadia. Frenk touches on the power struggles at the Elizabethan court that Sidney observed and that might have influenced his composition of the New Arcadia. Furthermore, he investigates its editing history that displays different approaches to its status as a fragment and the necessity of its completion through happy endings.

Lena Steveker discusses Richard Brome's tragicomedy The Queen and Concubine with regard to its representation of the pastoral iconography of Charles I and of Stuart ideals of statecraft, showing that the play draws on Van Dyck's portraiture and on Charles I's masques as well as on Justus Lipsius's political concept of 'love'. She argues that the play promotes a 'politics of happiness' which affirms the Caroline ideology of royal rule.

Paula Barros's article investigates Sir Kenelm Digby's letters to his friends written after the sudden death of his wife, emphasising their creation of a close relationship between happiness, grief, the performance of mourning and their status as a 'sensory autobiography'. She explores the letters' negotiation of Aristotelian, Catholic and Neoplatonic concepts of happiness that is informed by a radically subjective and non-conformist ethics of self-care, an inversion of dominant gender roles, an idealisation of friendship in marriage and partly transgressive, desire-based and highly sexualised reconfigurations of Neoplatonic visions of the mystical union.

Christoph Ehland discusses John Ford's play 'Tis Pity She's a Whore as a compelling rendering of the state of happiness and a text that uses the term 'happiness' in an astonishing variety and complexity of ways. Its scandalous plot, depicting the incestuous relationship between the two siblings Giovanni and Annabella, confronts the audience with a daring, dynamic negotiation and appropriation of secular and theological notions of happiness. Ford's play, Ehland demonstrates, 'stages the conflicts and the calamities that derive from its protagonists' eager attempt to attain and to live their own version of happiness'. 
Katrin Röder is Lecturer in English Literature and Culture at the University of Potsdam, Germany. She is author of Macht und Imagination: Fulke Grevilles Konstruktion diskreter Autorschaft (Winter, 2006), a monograph which discusses Fulke Greville's works in the context of early modern authorship and censorship, and of Entwürfe des Glücks und des guten Lebens in englischen Romanen vom 18. zum 20. Jahrhundert (Winter, 2015), which investigates English literary narratives of happiness from the eighteenth to the twentieth century. She is co-editor of the volume Fulke Greville and the Culture of the English Renaissance (Oxford University Press, 2018). E-mail: kroeder@uni-potsdam.de

Christoph Singer is assistant professor in the Department of English and American Studies at the University of Paderborn. He is author of Sea Change: The Shore from Shakespeare to Banville (Brill, 2014), a monograph that explores literary representations of shorelines as liminal spaces, and co-editor of Dante and Milton: Envisioned Visionaries (Cambridge Scholars, 2015) and of Timescapes of Waiting: Spaces of Stasis, Delay and Deferral (Brill/Rodopi, 2019). E-mail: csinger@mail.uni-paderborn.de

\section{Notes}

1. Alexander Pope, Essay on Man, ed. Mark Pattison (Oxford: Clarendon Press, 1871), 58-59, Epistle IV, 11. 1-28.

2. Phil Withington, 'The Invention of "Happiness"', in Suffering and Happiness in England 1550-1850: Narratives and Representations, ed. Michael J. Braddick and Joanna Innes (Oxford: Oxford University Press, 2017), 23-44.

3. Ibid., 26-27.

4. Ibid., 27.

5. Paul Slack, 'The Politics of Consumption and England's Happiness in the Later Seventeenth Century', The English Historical Review 122.497 (2007): 609-663, 629-630. This meaning is related to the classical and scholastic Aristotelian traditions and became most significant during the sixteenth and seventeenth centuries. Withington reads Thomas Elyot's translation of Plutarch's The Education and Bringing Up of Children (1532) as an illustration of Platonic and Aristotelian notions of the good life and the pursuit of wisdom and virtue. He argues that it creates a hierarchy between happiness as active virtue and the notion of happiness as luck and fortune, suggesting that in the text "the cord between "happiness" and "hap" was broken' (Withington, 'Invention', 31).

6. Ibid., 25-26; Slack 629.

7. Niccolò Machiavelli, Il Principe, ed. L. Arthur Burd (Oxford: Clarendon, 1891), 178, 193, $206-$ 209, 213, 355-364; Niccolò Machiavelli, Discourses on Livy, trans. Harvey C. Mansfield and Nathan Tarcov (Chicago: University of Chicago Press, 1996), 78; Niccolò Machiavelli, Discorsi sopra la prima Deca di Tito Livio, in Machiavelli: Tutte le opere, ed. Mario Martelli (Florence: Sansoni, 1971), 95. Machiavelli argues that human desire causes the tragic vicissitudes of life.

8. According to Sara Ahmed, it is the aspect of contingency that makes happiness difficult to achieve. 'Happiness,' she writes, 'cannot eliminate the hap of what happens. Happiness means living with the contingency of this world, even when we aim to make happiness necessary.' Sara Ahmed, The Promise of Happiness (Durham, NC: Duke University Press, 2010), 31. 
9. Isabella Whitney, 'A Careful Complaint by the Unfortunate Author', in A sweet nosgay, or pleasant posye: contayning a hundred and ten phylosophicall flowers ... (R. Jones, 1573), Sig. Diii 1. 7.

10. Ibid., Sig. Diii 1. 28.

11. Kathryn Pratt, “'Wounds still curelesse”: Estates of Loss in Mary Wroth's Urania', in Privacy, Domesticity, and Women in Early Modern England, ed. Corinne S. Abate (Aldershot: Ashgate, 2003), 45-64, here 46. For the use of 'hap', see Lady Mary Wroth, The First Part of the Countess of Montgomery's Urania (Tempe: Medieval \& Renaissance Texts \& Studies, 1995), 327-328.

12. Adam Potkay, The Passion for Happiness: Samuel Johnson and David Hume (Ithaca, NY: Cornell University Press, 2000), 65; Slack, 'Politics of Consumption', 629-630; Ahmed, Promise of Happiness, 4; Paul Dolan, Happiness by Design: Finding Pleasure and Purpose in Everyday Life (London: Penguin, 2014), 6-7; William Davies, The Happiness Industry: How the Government and Big Business Sold Us Well-Being (London: Verso, 2015), 13-39; Withington, 'Invention', 24.

13. Keith Thomas, The Ends of Life: Roads to Fulfilment in Early Modern England (Oxford: Oxford University Press, 2009).

14. Joanna Innes and Michael J. Braddick, 'Introduction', in Braddick and Innes, Suffering and Happiness in England 1550-1850, 1-20, here 6.

15. Withington, 'Invention', 24.

16. Ibid., 25 .

17. Withington refers to the use of 'happiness' in religious contexts and the use of 'felicity' in secular ones in Hobbes's Leviathan. The negotiation of these concepts in Hobbes's text, however, remains unexamined; see Withington, 'Invention', 43-44.

18. Withington, 'Invention', 42.

19. Michel Foucault, Ethics: Subjectivity and Truth, ed. Paul Rabinow (New York: The New Press, 1997), 212-214.

20. John Locke describes a linear succession of such states; see Locke: An Essay Concerning Human Understanding (Ware: Wordsworth Editions Limited, 2014), 245, $2.21 \rrbracket 41$.

21. On a linear, sequential and substitutional relationship between states of suffering and pleasure/happiness, see Alexandra Walsham, 'The Happiness of Suffering: Adversity, Providence, and Agency in Early Modern England', in Braddick and Innes, Suffering and Happiness in England 1550-1850, 45-64, here 53, 61.

22. This dialectical relationship between happiness and unhappiness is emphasised in Vivasvan Soni's advocation of a tragic, Solonian concept of happiness; see Vivasvan Soni, Mourning Happiness: Narrative and the Politics of Modernity (Ithaca, NY: Cornell University Press, 2010), $16,111-112$.

23. Foucault, Ethics, 287, 265.

24. The ethical substance of classical Greek philosophy, Foucault states, is 'the aphrodisia, which are at the same time acts, desire, and pleasure. ... It is that we have to build our existence as a beautiful existence; it is an aesthetic mode'. To Foucault, the classical Greek conceptions of the good life represent a 'strong structure of existence' with the 'idea of the bios as a material for an aesthetic piece of art', an 'aesthetics of existence' with a prominent relation to political ethics (ibid., 266, 260).

25. Stephen Greenblatt, Renaissance Self-Fashioning: From More to Shakespeare (Chicago: University of Chicago Press, 1980), 9, 23, 32-33, 57.

26. Ibid., 44-45, 49-50.

27. Even the invention of religion is discussed as a pragmatic response to the pursuit of pleasure as the dominant form of existence; Stephen Greenblatt, 'Utopian Pleasure', in Cultural Reformations: Medieval and Renaissance in Literary History, ed. Brian Cummings and James Simpson (Oxford: Oxford University Press, 2010), 305-320, here 308, 317, 319.

28. Karl Hardy, 'Unsettling Hope: Contemporary Indigenous Politics, Settler Colonialism, and Utopianism', Spaces of Utopia: An Electronic Journal, 2nd series, no. 1 (2012), 123-136, here $125,<$ https://ler.letras.up.pt/site/default.aspx?qry=id05id174id2587\&sum=sim>.

29. Thomas More, Utopia, trans. Paul Turner (London: Penguin, 1965), 69-70, 80. 